\title{
Discussion on Foreign Affairs Management in Agricultural Research Units
}

\author{
Shaoshan Liu, Xiuhua Wang, Yonghua Liu, Lizhen Chen \\ Tropical Crops Genetic Resources Institute, Chinese Academy of Tropical Agricultural Sciences, Hainan, \\ Haikou, 571101
}

Keywords: agricultural research unit; foreign affairs management personnel; quality system construction; file management

\begin{abstract}
The management of foreign affairs in agricultural research units is an important part of the work of agricultural research institutes and is closely linked to scientific research and development. The paper analyzes the main problems in the management of foreign affairs of agricultural research institutes, discusses the improvement of the quality of foreign affairs management team, the improvement of system construction, the strengthening of foreign affairs file management, and puts forward suggestions for improving the management level of foreign affairs in agricultural research units.
\end{abstract}

\section{Introduction}

The foreign affairs management of agricultural research is an important part of the daily administrative work of agricultural research institutes. It is closely linked with the central work of the unit and directly serves agricultural research and production. Foreign affairs management is not only a bridge for Chinese agriculture to "go global", but also to strengthen international exchanges and cooperation. It is also an important channel for absorbing foreign advanced agricultural technology and management experience and sharing. Doing a good job in the management of foreign affairs in agricultural research is conducive to enhancing the reputation, image and international status of scientific research units.

In the new era, the main foreign affairs work of agricultural research units includes the following parts: according to the development strategy of the research institutes, formulate specific policies and work plans corresponding to foreign affairs, so that foreign affairs work closely around and serve scientific research and production; International academic exchanges, academic lectures and various training courses, scientific and technological cooperation, negotiation, etc., and responsible for the reception work of foreign experts; in accordance with relevant policies and regulations, the examination and approval will be sent to the country every year to participate in various academic activities and scientific research, training, training, Execution procedures for professional and technical personnel and management personnel such as international cooperation projects; responsible for international cooperation project management; management of foreign experts and scholars who are responsible for long-term or short-term work, training, exchanges, inspections, visits, etc. in research institutes. As a foreign affairs manager of an agricultural research unit, we must first have a clear and thorough understanding of the importance of external affairs management and its corresponding functions, and then take all necessary organizational management tools to make reasonable planning for each work link. Establish a foreign affairs management mechanism with the best operational performance.

\section{The Existing Problems}

In actual work, due to problems in personnel, systems, and archives, foreign affairs management is inefficient and cannot meet the needs of foreign affairs management work in the new period.

\subsection{The Poor Overall Quality of Management Personnel.}

The foreign affairs management departments of agricultural research institutes are often not set 
up separately, usually located in the office, personnel department or scientific research management department of the unit. Therefore, most of the foreign affairs staff are part-time, which will inevitably lead to the lack of standardization of foreign affairs. In reality, scientific research personnel have gone abroad to implement national cooperation projects for private passports, science and technology personnel to go abroad to participate in international academic activities, and foreign affairs personnel are unaware of the fact that the phenomenon of non-compliance with the regulations governing the administration of the country (the territory) has occurred frequently. Statistics and summary of foreign affairs work. At the same time, in the new era, foreign affairs activities often involve issues such as the use of funds, the issue of intellectual property rights, and the docking of international science and technology cooperation plans with other national science and technology programs, which have become a new topic in foreign affairs management. Due to the lack of language and business ability, part-time staff cannot complete management tasks in an efficient and orderly manner.

\subsection{The Imperfect Foreign Affairs Management System.}

Agricultural research institutes often establish various types of scientific research project management systems but do not specify the supporting international cooperation project management methods. For example, there are entry and exit management systems that cannot meet the actual needs. Therefore, it is urgent to actively implement the "integrated" management model. Under the principle of "unified leadership, centralized management, specific responsibility, coordination and coordination", a special foreign affairs management institution will be established to implement a centralized and unified management model and improve the system construction. Management and service are integrated, so that all aspects of agricultural management foreign affairs management work, all matters have rules to follow.

\subsection{The Weak Management of Foreign Affairs Files.}

Agricultural research institutes often pay insufficient attention to foreign affairs archives. Usually there are no special foreign affairs archives, and foreign affairs archives are even more scarce. Foreign documents are usually kept in the hands of certain personnel or personnel. The archives can no longer be found, and the development of the unit's foreign affairs development plan lacks valuable information wealth. In order to strengthen the management of foreign affairs archives, agricultural research institutes must separately store foreign affairs files and formulate file management methods, systematically collect and organize various archives such as daily affairs of foreign affairs, international cooperation technology projects, important foreign affairs documents, etc., and be equipped with special foreign affairs file management. The personnel are responsible for the management of foreign affairs files.

\section{Solutions}

\subsection{Improve Overall Quality.}

Establish a dedicated team of foreign affairs management personnel, strengthen the training of foreign affairs management personnel, clarify the guiding ideology, construction objectives and main tasks of foreign affairs management work, and improve the personnel quality and business capabilities of foreign affairs management personnel of agricultural research institutions.

First of all, foreign affairs managers must have a strong political literacy. In politics, we must maintain a high degree of consistency with the Party Central Committee, conscientiously abide by the discipline of foreign affairs, strengthen the sense of secrecy, and grasp the principles and standards in foreign exchanges to ensure that state secrets and secrets related to the research and production of the Institute are not leaked. The land guarantees the interests of the state and the institution without loss. Second, foreign affairs managers must have a good level of foreign language. Through language training, we have a high level of listening, speaking, reading, writing and translating. We can read professional literature, participate in international academic seminars, 
and speak in foreign languages. We can work with foreign researchers. Communicate and discuss, and be able to write papers in foreign languages. Finally, foreign affairs managers should also strengthen their business capabilities. By strengthening the training of their own professional knowledge, it is conducive to dealing with the needs of foreign affairs visits and dispatched projects and the understanding of the project.

\subsection{Establish a Sound System.}

Formulate medium- and long-term development plans, clarify the guiding ideology, construction goals and main tasks of the work, and guide international exchanges and cooperation with the scientific development concept, aiming at improving scientific research competitiveness, international influence and internationalization level, and thoroughly implement the full implementation The open-minded development strategy will continue to expand opening up, enrich the content of domestic and international cooperation and exchanges, adhere to pragmatic cooperation, efficient cooperation and long-term cooperation, build a mutually beneficial and win-win external cooperation platform, and promote the healthy development of international exchanges and cooperation.

We will improve the work expenditure and expenditure mechanism for scientific and technological introduction, scientific and technological academic exchanges, scientific and technological personnel exchanges, and scientific and technological foreign affairs reception. Only by establishing an effective management system, including supervision and inspection mechanisms and incentive mechanisms, can each work be disciplined, orderly, correct, and enthusiasm, and fully mobilize all aspects of enthusiasm and enhance The sense of responsibility of the employees, so as to comprehensively improve the level of foreign affairs management and the quality of foreign affairs services.

\subsection{Standard File Management.}

The foreign affairs management department shall have part-time or full-time archivists responsible for organizing and collecting foreign affairs files, and shall regularly participate in the training of foreign affairs archives work and the exchange of system files. The content of foreign affairs activities is relatively extensive. The foreign affairs files should include various foreign affairs documents, planning arrangements, summary reports, meeting minutes, cooperation agreements, correspondence and other contents. Each item should be recorded in detail and regularly arranged and bound. , classified, and kept separately. The detailed foreign affairs file is an important part of the foreign affairs management work. It is not only a work record, but also indispensable information for daily work of foreign affairs. It helps us to better summarize the foreign work experience and formulate the next work plan. There is no small matter in foreign affairs, and we must not neglect the work of organizing and archiving files. The perfect foreign affairs archives work is an important indicator of the unit's high-quality and efficient foreign affairs communication ability.

To sum up, foreign affairs managers must seize the opportunity, make full use of the convenience brought by information technology, break the constraints of traditional management concepts, constantly innovate management mechanisms, and seek a more scientific, automated, and systematic management model. The foreign affairs management department should diligently think in the usual work, diligently sum up, and strive to make the foreign affairs work more closely related to the central work of the whole hospital, and the service is better and better.

\section{References}

[1] Di Yu, Xu Wei, Fei Xiaojun. Sustainable Development of Foreign Affairs Management in Scientific Research Institutes [J]. Agricultural Research Economic Management, 2013 (2): 10-13.

[2] Yang Wei. Strengthening international cooperation and exchanges in agricultural science and technology [J]. Agricultural Research Economic Management, 1999, (4): 41. 
[3] Zhou Pan, Zhou Yiqi, Liu Xiao et al. On the quality and ability of agricultural scientific research personnels in the new era [J]. Agricultural Science and Technology Management, 2012 (8): 94-96.

[4] Wang Wei, Wang Wei, Jiang Jianbing. Factors and Countermeasures Affecting the Efficiency of Agricultural Scientific Research Management [J]. Tianjin Agricultural Sciences, 2014(10): 112-114.

[5] Wang Fu, Sun Haoqin, Zhang Huijian. Research on the Development Strategy of International Cooperation in Tropical Agricultural Science and Technology in China [J]. Chinese Agricultural Science Bulletin, 2010, 26(23): 349-353.

[6] Liu Meng. Research on the efficiency improvement of agricultural scientific research management [J]. Tropical Agriculture Engineering, 2013 (10): 46-48. 